\title{
Penerapan Asuhan Keperawatan Psikososial Dengan Masalah Ansietas Pada Penderita Diabetes Mellitus: Studi Kasus
}

\section{ADAM ASHORI}

adamansor6@gmail.com

\section{BAB 1 \\ PENDAHULUAN}

\subsection{Latar Belakang}

Diabetes Mellitus adalah kondisi kronik dan berhubungan dengan komplikasi seperti neurophathy, nephropathy, retinophaty, dan kaki diabetik yang merupakan kondisi isu berbahaya dalam masalah kesehatan (Irawan,2018). Menurut American Diabetes Association (2017), Diabetes mellitus adalah penyakit metabolik dengan karakteristik hiperglikemia yang terjadi karena kelainan sekresi insulin, dan gangguan kerja insulin keduanya. Sedangkan menurut World Health Organization (2017), Diabetes mellitus adalah penyakit kronis yang terjadi baik saat pankreas tidak menghasilkan cukup insulin atau bila tubuh tidak dapat secara efektif menggunakan insulin yang dihasilkannya.

Prevalensi diabetes melitus di dunia diperkirakan mencapai 463 juta jiwa (9,3\% jumlah penduduk dunia) pada usia 20 - 79 tahun dengan kematian mencapai 4,2 juta jiwa. Bahkan di tahun selanjutnya, diabetes melitus diperkirakan akan terus meningkat sampai 700,2 juta jiwa pada tahun 2045 (Federation, 2019). Amerika Serikat pada tahun 2018 diperkirakan terdapat 34,2 juta orang (10,5\%) populasi hidup dengan diabetes (Report,2020). Sedangkan prevalensi di Indonesia tahun 2018 terdapat $2 \%$ penduduk dengan diabetes melitus pada usia di atas 15 tahun. Prevalensi diabetes melitus tertinggi di Jakarta $(3,4 \%)$, kemudian DIY $(3,1 \%)$, dan Kalimantan Timur (3,1\%) (Report, 2020) 
Pasien diabetes mellitus sudah pasti mengalami gangguan pada kondisi psikologis berupa rasa cemas akan penyakit yang dideritanya serta depresi terhadap kadar gula darah yang sewaktu-waktu melakukan kontrol bisa naik berkisar 400mg/dl berupa hiperglikemi maupun turun secara tiba(Mahmuda,Thohirun,\&Prasetyowati,2016)

Ansietas merupakan perasaan takut atau ketakutan yang tidak dapat dijelaskan dan merupakan respon stimulus internal dan eksternal yang memiliki tanda dan gejala perilaku, afektif, kognitif dan fisik. Ansietas merupakan suatu respons emosional sebagai antisipasi terhadap bahaya. Respon individu terhadap ansietas mempunyai rentang antara adaptif sampai maladaptif. Respon adaptif identik dengan reaksi bersifat destruktif. Reaksi yang bersifat kontruktif menunjukan sikap optimis dan berusaha memahami terhadap perubahan-perubahan yang terjadi baik perubahan fisik maupun efektif. (Marbun, Pardede \& Perkasa, 2019)

Tekanan secara terus menerus akan bisa menjadi stress, kemudian dari stress berlanjut menjadi perasaan cemas yang dapat terjadi pada keadaan kesehatan jiwa individu pada segi kesehatan fisik, psikologi, maupun keadaan sosial lingkungannya. Ansietas (Kecemasan) yang bisa berlanjut pada status kesehatan jiwa akibat dari rasa takut dan khawatir mengenai terjadinya sesuatu hal yang akan menimpa kehidupan serta bisa berlanjut secara terus menerus dalam diri individu tersebut (Stuart \& Sundeen, 2017).Dampak pada pasien diabetes yang mengalami Ansietas yaitu klien akan menjadi pendiam, menarik diri dan tidak aktif lagi. Komplikasi dapat menyebabkan kecemasan meningkat, diikuti dengan respon kehilangan, gangguan harga diri, hubungan keluarga, yang akhirnya beresiko terhadap semua aspek dalam kehidupan sehari-hari dari individu tersebut (Achmad, 2015).

Komplikasi diabetes mellitus dapat menyebabkan kehidupan sehari-hari lebih sulit sehingga menimbulkan kesedihan yang berkepanjangan (Mutaminah,2017). Pasien Diabetes mellitus memiliki tingkat kecemasan terkait dengan penatalaksanaan yang harus dipatuhi meliputi pengaturan makan, pemeriksaan kadar gula darah, konsumsi obat, olahraga dan perawatan kaki. Ansietas yang tidak segera diatasi akan mempengaruhi dalam penatalaksanaan diabetes melitus 
(Mahmuda, 2016). Survei awal yang dilakukan di Jalan Anggrek Raya, Medan Helvetia ditemukan pasien dengan masalah gangguan Ansietas akibat diabetes melitus yang bernama Ny.R. Dari uraian diatas penulis tertarik memberikan perawatan dengan judul : Asuhan Keperawatan Psikososial Pada Ny.R Dengan Masalah Ansietas Di Jalan Anggrek Raya Kecamatan Medan Helvetia.

\subsection{Tujuan}

\subsubsection{Tujuan Umum}

Memberikan asuhan keperawatan pada Ny.R dengan masalah ansietas di Jalan Anggrek Raya Kecamatan Medan Helvetia.

\subsubsection{Tujuan Khusus}

1. Mahasiswa mampu melakukan pengkajian pada klien Ny.R dengan masalah ansietas.

2. Mahasiswa mampu merumuskan diagnosa keperawatan pada klien Ny.R dengan masalah ansietas.

3. Mahasiswa mampu menyusun rencana keperawatan pada klien Ny.R dengan masalah ansietas.

4. Mahasiswa mampu melakukan implementasi pada klien Ny.R dengan masalah ansietas.

5. Mahasiswa mampu melakukan evaluasi pada klien Ny.R dengan masalah ansietas. 


\section{BAB 2}

\section{LANDASAN TEORI}

\subsection{Konsep Diabetes Mellitus}

\subsubsection{Definisi}

Diabetes mellitus adalah penyakit yang ditandai dengan terjadinya hiperglikemia dan gangguan metabolisme karbohidrat, lemak, dan protein yang dihubungkan dengan kekurangan secara absolut atau relatif dari kerja dan atau sekresi insulin (Buraerah, 2015).

\subsubsection{Tanda dan Gejala}

a. Gejala akut

Polifagia (banyak makan), polidipsia (banyak minum), poliuria (banyak kencing atau sering kencing di malam hari), nafsu makan bertambah namun berat badan turun dengan cepat (5-10 $\mathrm{kg}$ dalam waktu 2-4 minggu), dan mudah lelah.

b. Gejala kronik

Kesemutan, kulit terasa panas atau seperti tertusuk tusuk jarum, rasa kebas di kulit, kram, kelelahan, mudah mengantuk, pandangan mulai kabur, gigi mudah goyah dan mudah lepas, kemampuan seksual menurun bahkan pada pria bisa terjadi impotensi, pada ibu hamil sering terjadi keguguran atau kematian janin dalam kandungan atau dengan bayi berat lahir lebih dari 4kg (Fatimah, 2015).

\subsubsection{Klasifikasi}

Klasifikasi etiologi DM menurut American Diabetes Association 2010 (ADA 2012), dibagi dalam 4 jenis yaitu:

a. Diabetes mellitus tipe 1 atau Insulin Dependent

Diabetes Mellitus/IDDM DM tipe 1 terjadi karena adanya destruksi sel beta pankreas karena sebab autoimun. Pada DM tipe 1 ini terdapat sedikit atau tidak sama sekali sekresi insulin dapat ditentukan dengan level protein cpeptida yang jumlahnya sedikit atau tidak terdeteksi sama sekali. Manifestasi klinik pertama dari penyakit ini adalah ketoasidosis. 
b. Diabetes mellitus tipe 2 atau Insulin Non-dependent Diabetes Mellitus/NIDDM

Pada penderita DM tipe ini terjadi hiperinsulinemia tetapi insulin tidak bisa membawa glukosa masuk kedalam jaringan karena terjadi resistensi insulin yang merupakan turunnya kemampuan insulin untuk merangsang pengambilan glukosa oleh jaringan perifer dan untuk menghambat produksi glukosa oleh hati. Oleh karena terjadinya resistensi insulin (reseptor insulin sudah tidak aktif karena dianggap kadarnya masih tinggi dalam darah) akan mengakibatkan defisiensi relatif insulin. Hal tersebut dapat mengakibatkan berkurangnya sekresi insulin pada adanya glukosa bersama bahan sekresi insulin lain sehingga sel beta pankreas akan mengalami desensitisasi terhadap adanya glukosa. Onset DM tipe ini terjadi perlahanlahan karena itu gejalanya asimtomatik. Adanya resistensi yang terjadi perlahan-lahan akan mengakibatkan sensitivitas reseptor akan glukosa berkurang. DM tipe ini sering terdiagnosis setelah terjadi komplikasi.

\subsubsection{Ansietas pada Pasien DM}

Diabetes mellitus adalah salah satu penyakit endokrin yang paling banyak diderita penduduk diseluruh dunia. Menurut ADA, diabetes mellitus adalah suatu kumpulan gejala yang timbul pada seseorang yang disebabkan oleh karena adanya peningkatan kadar glukosa darah akibat penurunan sekresi insulin yang progresif (American Diabetes Association, 2015). Penderita DM mengalami banyak perubahan dalam hidupnya, mulai dari pengaturan pola makan, olah raga, kontrol gula darah, dan lain-lain yang harus dilakukan sepanjang hidupnya. Perubahan dalam hidup yang mendadak membuat penderita DM menunjukkan beberapa reaksi psikologis yang negatif diantaranya adalah marah, merasa tidak berguna, kecemasan yang meningkat dan depresi (Shahab, 2008). Ansietas adalah perasaan was-was, khawatir, atau tidak nyaman seakan-akan terjadi sesuatu yang dirasakan sebagai ancaman (Keliat, 2011, dan Videbeck, 2008). Kecemasan ini apabila tidak ditangani secara baik maka akan menimbulkan masalah tersendiri yang akan semakin menyulitkan dalam pengelolaan DM (Hastuti, 2008). 
Berdasarkan konsep psikoneuroimunologi, kecemasan merupakan stressor yang dapat menurunkan sistem imunitas tubuh. Hal ini terjadi melalui serangkaian aksi dan diperantai oleh HPA-axis (Hipotalamus, Pituitari dan Adrenal). Stress dapat merangsang hipotalamus untuk meningkatkan psoduksi CRF (Cortictropin Releasing Factor). CRF ini selanjutnya akan merangsang kelenjar pituitari anterior untuk meningkatkan produksi ACTH (Adreno Cortico Tropin Hormon). Hormon ini yang akan merangsang kortek adrenal untuk meningkatkan sekresi kortisol. Kortisol inilah yang selanjutnya akan menekan sistem imun tubuh (Guyton \& Hall, 2012). Ansietas dapat diatasi dengan tehnik relaksasi, distraksi, kegiatan spiritual dan hipnoterapi (Keliat, 2015). Ada beberapa jenis hipnosis yang bisa dilakukan salah satunya yaitu hipnosis dengan menggunakan tehnik hipnosis 5 jari tangan. Individu atau klien dibantu merubah persepsi ansietas, stress, tegang dan takut dengan menerima saran-saran di ambang bawah sadar atau dalam keadaan rileks dengan menggerakan jari-jarinya sesuai perintah (Long, 2013).

\subsection{Konsep Ansietas}

\subsubsection{Defenisi}

Ansietas adalah perasaan emosional dan tidak nyaman sehingga individu akan meningkatkan kewaspadaan untuk mengantisipasi. Individu yang mengalami ansietas biasanya mereka merasa dirinya tidak bebas, gugup, takut, gelisah, tegang dan resah. Perasaan yang tidak menentu tersebut umunya tidak menyenangkan yang nantinya akan menimbulkan atau disertai perubahan fisiologi dan psikologis (Hulu \& Pardede, 2016) Ansietas adalah perasaan tidak senang yang khas yang disebabkan oleh dugaan akan bahaya atau frustasi yang mengancam yang akan membahayakan rasa aman, keseimbangan, atau kehidupan seseorang individu atau kelompok biososialnya. (Pardede \& Simangungsong, 2020)

Ansietas adalah kondisi emosi dan pengalaman subjektif individu terhadap objek yang tidak jelas dan spesifik akibat antisipasi bahaya yang memungkinkan individu melakukan tindakan untuk menghadapi ancaman (PPNI, 2016). Sedangkan menurut NANDA (2015) ansietas adalah perasaan tidak nyaman atau kekhawatiran yang samar disertai respon otonom (sumber tidak diketahui oleh individu) sehingga individu akan meningkatkan kewaspadaan untuk mengantisipasi. Jadi ansietas 
adalah kekhawatiran yang tidak jelas, berkaitan dengan perasaan tidak berdaya dan respon emosional terhadap penilaian sesuatu.

\subsubsection{Etiologi Ansietas.}

Menurut Donsu, (2017) Ada beberapa faktor yang mempengaruhi anxiety, yaitu :

a. Faktor Presdisposisi

1. Biologi

Suatu model biologis yang menerangkan bahwa ekspresi emosi yang melibatkan struktur anatomi dalam otak dan aspek biologis ini menerangkan adanya pengaruh neurotransmitter yang dapat menyebabkan kecemasan. Dikatakan bahwa ada 3 jenis neurotransmiten yang berhubungan dengan anatomi otak yang dapat mempengaruhi kecemasan adalah norepineprin, serotonin dan gamma-aminobutyric acid (GABA).

2. Psikologis

Suliswati (2005) dalam Donsu (2017) menjelaskan bahwa ketegangan dalam kehidupan yang dapat menimbulkan anxiety diantaranya adalah suatu tragedi yang membuat trauma baik krisis perkembangan maupun situasional seperti terjadinya bencana, konflik emosional individu yang terselesaikan dengan baik serta mengalami konsep diri yang terganggu.

3. Sosial Budaya

Adanya riwayat gangguan anxiety dalam keluarga yang mempengaruhi respon individu dalam bereaksi terhadap konflik dan cara mengatasi kecemasan. Dikatakan bahwa faktor-faktor yang mempengaruhi terjadinya kecemasan adalah social budaya, potensi stress, serta lingkungan.

b. Faktor Prespitasi

Digambarkan oleh Stuart \& Laraia (2005), yang dikutip dalam Donsu, (2017) bahwa stresor pencetus sebagai stimulant yang 
dipersepsikan oleh individu sebagai tantangan, ancaman, atau tuntutan untuk mempertahankan diri bisa dari internal maupun eksternal. Kesehatan umum seseorang akan memiliki efek yang nyata sebagai presipitasi terjadinya kecemasan. Apabila seseorang sudah mengalami gangguan pada kesehatan akan berakibat pada kemampuan seseorang dalam mengatasi ancaman berupa penyakit akan menurun, lalu kondisi psikologis juga dapat menyebabkan suatu keadaan kecemasan seperti kematian, perceraian,dan dilema etik, dan status sosial ekonomi seseorang dapat juga mempengaruhi timbulnya stress yang akan berakibat terjadinya kecemasan.

\subsubsection{Tanda dan Gejala Ansietas}

Menurut PPNI (2016) tanda dan gejala ansietas

Gejala dan Tanda Mayor Ansietas

\begin{tabular}{|l|l|}
\hline \multicolumn{1}{|c|}{ Subjektif } & Objektif \\
\hline Merasa bingung & $\begin{array}{l}\text { Tampak } \\
\text { gelisah }\end{array}$ \\
\hline Merasa khawatir dengan akibat dari kondisi yang dihadapi & $\begin{array}{l}\text { Tampak } \\
\text { tegang }\end{array}$ \\
\hline Tampak tegang & $\begin{array}{l}\text { Sulit } \\
\text { tidur }\end{array}$ \\
\hline
\end{tabular}

Sumber : PPNI, Standar Diagnosis Keperawatan Indonesia (2016)

Gejala dan Tanda Minor Ansietas

\begin{tabular}{|l|l|}
\hline \multicolumn{1}{|c|}{ Subjektif } & \multicolumn{1}{c|}{ Objektif } \\
\hline Mengeluh pusing & Frekuensi nafas meningkat \\
\hline Anoreksia & Frekuensi nadi meningkat \\
\hline Palpitasi & Tekanan darah meningkat \\
\hline Tremor & $\begin{array}{l}\text { Muka tampak pucat } \\
\text { Suara bergetar } \\
\text { Kontak mata buruk } \\
\text { Sering berkemih } \\
\text { Berorientasi pada masa lalu }\end{array}$ \\
\hline
\end{tabular}

Sumber : Standar Diagnosis Keperawatan Indonesia (2016) 


\subsubsection{Patofisiologi Ansietas}

Sistem syaraf pusat menerima suatu persepsi ancaman. Persepsi ini timbul akibat adanya rangsangan dari luar dan dalam yang berupa pengalaman masa lalu dan faktor genetik. Kemudian rangsangan dipersepsi oleh panca indra, diteruskan dan direspon oleh sistem syaraf pusat melibatkan jalur cortex cerebri - limbic system - reticular activating system - hypothalamus yang memberikan impuls kepada kelenjar hipofise untuk mensekresi mediator hormonal terhadap target organ yaitu kelenjar adrenal yang kemudian memicu syaraf otonom melalui mediator hormonal yang lain (Owen,2016).

\subsubsection{Penatalaksanaan Ansietas}

Menurut Hawari, (2016) penatalaksanan ansietas pada tahap pencegahan maupun terapi memerlukan suatu metode pendekatan yang bersifat holistik, mancakup fisik (somatik), psikologik atau psikososial dan psikoreligius. Adapun penatalaksanaan yang dapat dilakukan, yaitu:

a. Upaya peningkatan kekebalan terhadap stress, dengan cara:

1. Makan makanan yang bergizi seimbang

2. Tidur yang cukup

3. Olahraga yang cukup

4. Tidak merokok

5. Tidak meminum minuman keras

b. Terapi psikofarmaka

Terapi psikofarmaka merupakan pengobatan untuk cemas dengan memakai obat-obatan yang berkhasiat memulihkan fungsi gangguan neurotransmiter (sinyak penghantar saraf) di susunan saraf pusat otak (limbic System). Terapi psikofarmaka yang sering dipakai adalah obat anti cemas (anxiolitic), yaitu diazepam, clobazam, bromazepam, lorazepam, buspironeHCL, meprobamate dan alparazolam.

c. Terapi somatik 
Gejala atau keluhan fisik (somatik) sering dijumpai sebagai gejala penyerta atau akibat dari kecemasan yang berkepanjangan. Untuk menghilangkan keluhan-keluhan somatik (fisik) itu dapat diberikan obatobatan yang ditujukan pada organ tubuh yang bersangkutan.

\section{d. Psikoterapi}

Psikoterapi diberikan tergantung dari kebutuhan individu, antara lain:

1. Psikoterapi suportif, untuk memberikan motivasi semangat atau dorongan agar pasien yang bersangkutan tidak merasa putus asa dan diberi keyakinan serta percaya diri.

2. Psikoterapi re-edukatif, memberikan pendidikan ulang dan koreksi bila dinilai bahwa ketidakmampuan mengatasi kecemasan.

3. Psikoterapi re-konstruktif, untuk dimaksudkan memperbaiki (rekonstruksi) kepribadian yang telah mengalami goncangan akibat stressor.

4. Psikoterapi kognitif, untuk memulihkan fungsi kognitif pasien yaitu kemampuan untuk berpikir secara rasional, konsentrasi dan daya ingat.

5. Psikoterapi psikodinamik, untuk menganalisa dan menguraikan proses dinamika kejiwaan yang dapat menjelaskan mengapa seseorang tidak mampu menghadap sressor psikososial sehingga mengalami kecemasan.

6. Psikoterapi keluarga, untuk memperbaiki hubungan kekeluargaan agar faktor keluarga tidak lagi menjadi faktor penyebab dan faktor keluarga dapat dijadikan sebagai faktor pendukung.

7. Terapi psikoreligius, untuk meningkatkan keimanan seseorangyang erat hubungannya dengan kekebalan dan daya tahan dalam menghadap berbagai problem kehidupan yang merupakan stressor psikososial

\subsection{Konsep Asuhan Keperawatan}

\subsubsection{Pengkajian}

1. Faktor Predisposisi

Berbagai teori telah dikembangkan untuk menjelaskan asal ansietas :

a. Teori Psikoanalitik Ansietas adalah konflik emosional yang terjadi antara dua elemen kepribadian, ID dan superego. ID mewakili dorongan insting 
dan impuls primitif seseorang, sedangkan superego mencerminkan hati nurani seseorang dan dikendalikan oleh norma-norma budaya seseorang. Ego atau $\mathrm{Aku}$, berfungsi menengahi hambatan dari dua elemen yang bertentangan dan fungsi ansietas adalah mengingatkan ego bahwa ada bahaya.

b. Teori Interpersonal Ansietas timbul dari perasaan takut terhadap tidak adanya penerimaan dari hubungan interpersonal. Ansietas juga berhubungan dengan perkembangan, trauma seperti perpisahan dan kehilangan sehingga menimbulkan kelemahan spesifik. Orang dengan harga diri rendah mudah mengalami perkembangan ansietas yang berat.

c. Teori Perilaku Ansietas merupakan produk frustasi yaitu segala sesuatu yang mengganggu kemampuan seseorang untuk mencapai tujuan yang diinginkan.Daftar tentang pembelajaran meyakini bahwa individu yang terbiasa dalam kehidupan dininya dihadapkan pada ketakutan yang berlebihan lebih sering menunjukkan ansietas pada kehidupan selanjutnya.

d. Kajian Keluarga Menunjukkan bahwa gangguan ansietas merupakan hal yang biasa ditemui dalam suatu keluarga.Ada tumpang tindih dalam gangguan ansietas dan antara gangguan ansietas dengan depresi.

e. Kajian Biologis Menunjukkan bahwa otak mengandung reseptor khusus benzodiazepine. Reseptor ini mungkin membantu mengatur ansietas penghambat dalam aminobutirik. Gamma neuroregulator (GABA) juga mungkin memainkan peran utama dalam mekanisme biologis berhubungan dengan ansietas sebagaimana halnya endorfin. Selain itu telah dibuktikan kesehatan umum seseorang mempunyai akibat nyata sebagai predisposisi terhadap ansietas. Ansietas mungkin disertai dengan gangguan fisik dan selanjutnya menurunkan kapasitas seseorang untuk mengatasi stressor.

2. Faktor Presipitasi

Stressor pencetus mungkin berasal dari sumber internal atau eksternal. Stressor pencetus dapat dikelompokkan menjadi 2 kategori :

a. Ancaman terhadap integritas seseorang meliputi ketidakmampuan fisiologis yang akan datang atau menurunnya kapasitas untuk melakukan aktifitas hidup sehari- hari. 
b. Ancaman terhadap sistem diri seseorang dapat membahayakan identitas, harga diri dan fungsi sosial yang terintegrasi seseorang.

\section{Perilaku}

Kecemasan dapat diekspresikan secara langsung melalui perubahan fisiologi dan perilaku dan secara tidak langsung melalui timbulnya gejala atau mekanisme koping dalam upaya melawan kecemasan. Intensitas perilaku akan meningkat sejalan dengan peningkatan tingkat kecemasan.

a. Respon Fisiologis Terhadap Ansietas

\begin{tabular}{|c|c|}
\hline Sistem Tubuh & Respons \\
\hline Kardiovaskuler & $\begin{array}{l}\text { - Palpitasi. } \\
\text { - Jantung berdebar. } \\
\text { - Tekanan darah meningkat dan denyut nadi menurun. } \\
\text { - Rasa mau pingsan dan pada akhirnya pingsan. }\end{array}$ \\
\hline Pernafasan & $\begin{array}{l}\text { - } \text { Napas cepat. } \\
\text { - } \text { Pernapasan dangkal. } \\
\text { - } \text { Rasa tertekan pada dada. } \\
\text { - Pembengkakan pada tenggorokan. } \\
\text { - } \text { Rasa tercekik. } \\
\text { - Terengah-engah. }\end{array}$ \\
\hline
\end{tabular}




\begin{tabular}{|c|c|}
\hline Neuromuskular & $\begin{array}{l}\text { - } \text { Peningkatan reflek. } \\
\text { - } \text { Reaksi kejutan. } \\
\text { - Insomnia. } \\
\text { - Ketakutan. } \\
\text { - Gelisah. } \\
\text { - Wajah tegang. } \\
\text { - Kelemahan secara umum. } \\
\text { - Gerakan lambat. } \\
\text { - Gerakan yang janggal. }\end{array}$ \\
\hline Gastrointestinal & $\begin{array}{l}\text { - Kehilangan nafsu makan. } \\
\text { - } \text { Menolak makan. } \\
\text { - Perasaan dangkal. } \\
\text { - Rasa tidak nyaman pada abdominal. }\end{array}$ \\
\hline & $\begin{array}{l}\text { - Rasa terbakar pada jantung. } \\
\text { - Nausea. } \\
\text { - Diare. }\end{array}$ \\
\hline Perkemihan & $\begin{array}{l}\text { - } \quad \text { Tidak dapat menahan kencing. } \\
\text { - } \quad \text { Sering kencing. }\end{array}$ \\
\hline Kulit & $\begin{array}{l}\text { - } \text { Rasa terbakar pada mukosa. } \\
\text { - } \text { Berkeringat banyak pada telapak tangan. } \\
\text { - } \text { Gatal-gatal. } \\
\text { - } \text { Perasaan panas atau dingin pada kulit. } \\
\text { - } \text { Muka pucat dan bekeringat diseluruh tubuh. }\end{array}$ \\
\hline
\end{tabular}


b. Respon Perilaku Kognitif

\begin{tabular}{|c|c|}
\hline Sistem & Respons \\
\hline Perilaku & $\begin{array}{l}\text { - } \text { Gelisah. } \\
\text { - } \text { Ketegangan fisik. } \\
\text { - } \text { Tremor. } \\
\text { - Gugup. } \\
\text { - } \text { Bicara cepat. } \\
\text { - } \text { Tidak ada koordinasi. } \\
\text { - Kecenderungan untuk celaka. } \\
\text { - } \text { Menarik diri. } \\
\text { - } \text { Menghindar. } \\
\text { - Terhambat melakukan aktifitas. }\end{array}$ \\
\hline & $\begin{array}{l}\text { - } \text { Gangguan perhatian. } \\
\text { - } \text { Konsentrasi hilang. } \\
\text { - } \text { Pelupa. } \\
\text { - Salah tafsir. } \\
\text { - Adanya bloking pada pikiran. } \\
\text { - Menurunnya lahan persepsi. } \\
\text { - Kreatif dan produktif menurun. } \\
\text { - } \text { Bingung. }\end{array}$ \\
\hline & $\begin{array}{l}\text { - } \quad \text { Khawatir yang berlebihan. } \\
\text { - Hilang menilai objektifitas. } \\
\text { - Takut akan kehilangan kendali. } \\
\text { - Takut yang berlebihan. }\end{array}$ \\
\hline
\end{tabular}




\begin{tabular}{|l|ll|}
\hline Afektif & $\bullet$ & Mudah terganggu. \\
$\bullet$ & Tidak sabar. \\
$\bullet$ & Gelisah. \\
$\bullet$ & Tegang. \\
$\bullet$ & Nerveus. \\
$\bullet$ & Ketakutan. \\
$\bullet$ & Alarm. \\
$\bullet$ & Tremor. \\
$\bullet$ & Gugup. \\
$\bullet$ & Gelisah. \\
\hline
\end{tabular}

\section{Sumber Koping}

Sumber koping menurut Yusuf, (2015) individu mengatasi anxiety dengan menggerakkan sumber koping di lingkungan. Sedangkan menurut Lilik, imam, dan amar (2016) sumber koping yang dapat mengatasi anxiety yaitu dengan kemampuan menyelesaikan masalah (mekanisme koping), dukungan sosial, keyakinan spiritual, dan faktor ekonomi. Penggunaan sumber koping yang tepat dapat mencegah terjadinya anxiety.

\section{Mekanisme Koping}

Ketika mengalami ansietas individu menggunakan berbagai mekanisme koping untuk mencoba mengatasinya dan ketidakmampuan mengatasi ansietas secara konstruktif merupakan penyebab utama terjadinya perilaku patologis. Ansietas tingkat ringan sering ditanggulangi tanpa yang serius.

Tingkat ansietas sedang dan berat menimbulkan 2 jenis mekanisme koping :

a. Reaksi yang berorientasi pada tugas, yaitu upaya yang disadari dan berorientasi pada tindakan untuk memenuhi secara realitis tuntutan situasi stress.

b. Mekanisme pertahanan ego, membantu mengatasi ansietas ringan dan sedang, tetapi jika berlangsung pada tingkat sadar dan melibatkan penipuan diri dan distorsi realitas, maka mekanisme ini dapat merupakan respon maladaptif terhadap stress. 


\subsubsection{Diagnosa Keperawatan}

Adapun diagnosa yang biasanya muncul adalah :

1. Koping Individu Tidak Efektif

2. Kecemasan

3. Ketidakberdayaan

4. Isolasi Sosial

5. Perubahan Proses Berfikir

\subsubsection{Intervensi keperawatan}

\section{Kecemasan}

Tujuan :

- Klien mampu mengenal pengertian penyebab tanda gejala dan akibat

- Klien mampu mengetahui cara mengatasi ansietas

- Klien mampu mengatasi ansietas dengan melakukan latihan relaksasi tarik nafas dalam

- Klien mampu mengatasi ansietas dengan melakukan latihan distraksi

- Klien mampu mengatasi ansietas dengan melakukan hipnotis lima jari

- Klien mampu merasakan manfaat dari latihan yang dilakukan

- Klien mampu membedakan perasaan sebelum dan sesudah latihan

Tindakan :

- Kaji tanda dan gejala ansietas dan kemampuan klien mengurangi kecemasan

- Jelaskan tanda dan gejala, penyebab dan akibat dari kecemasan

- Latihan cara mengatasi kecemasan :

1. Teknik relaksasi napas dalam

2. Distraksi : bercakap-cakap hal positif

3. Hipnotis 5 jari fokus padahal-hal yang positif

- Bantu klien melakukan latihan sesuai dengan jadwal kegiatan. 


\section{Koping tidak efektif}

Tujuan :

- Klien mampu mengetahui perubahan kondisi kesehatan dan kemampuannya mengatasi perubahan

- Klien mampu mengetahui pengertian tanda dan gejala penyebab serta akibat dari ketidakefektifan koping

- Klien mampu mengetahui cara mengatasi ketidakefektifan koping

- Klien mampu mengatasi masalah secara bertahap

- Klien mampu menggunakan sumber/daya sistem pendukung dalam mengatasi masalah

- Klien mampu merasakan manfaat latihan yang dilakukan

- Klien mampu mengembangkan koping yang efektif klien mampu merasakan manfaat sistem pendukung Tindakan :

a. Kaji tanda dan gejala ketidakefektifan koping

b. Jelaskan proses terjadinya ketidakefektifan koping

c. Diskusikan koping (upaya atau cara) mengatasi masalah pada masa lalu

d. Koping (upaya) yang berhasil dan tidak berhasil. Berikan pujian

e. Pemanfaatan sumber daya atau sistem pendukung dalam mengatasi masalah

f. Latihan menggunakan upaya menyelesaikan masalah saat ini dengan menggunakan cara lama yang berhasil atau cara baru.

- Buat daftar masalah yang dihadapi

- Buat daftar cara (lama dan baru) yang akan digunakan

- Pilih, latih, dan jadwalkan cara yang akan digunakan untuk masalah yang dihadapi

- Evaluasi hasil jika berhasil dibudidayakan jika kurang berhasil dipilih cara lain pada daftar cara nomor kedua

g. Latih menggunakan sistem pendukung yang teratur

h. Beri motivasi dan pujian atas keberhasilan klien mengatasi masalah

\section{Harga Diri Rendah}


Tindakan keperawatan untuk pasien harga diri rendah menurut (PPNI, 2018).

Promosi harga diri

Definisi: meningkatkan penilaian perasaan/persepsi terhadap diri sendiri atau kemampuan diri.

Tindakan:

1. Observasi

a. Identifikasi budaya, agama, ras, jenis kelamin, dan usia terhadap diri sendiri

b. Monitor verbalitasi yang merendahkan diri sendiri

c. Monitor tingkat harga diri setiap waktu, sesuai kebutuhan

2. Terapeutik

a. Motivasi terlibat dalam verbalisasi positif untuk diri sendiri

b. Motivasi menerima tantangan baru atau hal baru

c. Diskusikan kepercayaan terhadap penilaian diri

d. Diskusikan pengalaman yang meningkatkan harga diri

e. Diskusikan persepsi negatif diri

f. Diskusikan alasan mengkritik diri atau rasa bersalah

g. Diskusikan penetapan tujuan realistis untuk mencapai harga diri yang lebih jauh

h. Diskusikan bersama keluarga untuk menetapkan harapan dan batasan yang jelas

i. Berikan umpan balik positif atas peningkatan mencapai tujuan

j. Fasilitasi lingkungan dan aktivitas yang meningkatkan harga diri

\section{Edukasi}

a. Jelaskan kepada keluarga pentingnya dukungan dalam perkembangan konsep positif dari pasien

b. Anjurkan mengidentifikasi kekuatan yang dimiliki.

c. Anjurkan mempertahankan kontak mata saat berkomunikasi dengan orang lain

d. Anjurkan membuka diri untuk kritik negatif.

e. Anjurkan mengevaluasi perilaku.

f. Ajarkan cara mengatasi bullying. 
g. Latih peningkatan tanggung jawab untuk diri sendiri.

h. Latih pernyataan/kemampuan positif diri.

i. Latih cara berfikir dan berperilaku positif.

j. Latih meningkatkan kepercayaan pada kemampuan dalam menangani situasi.

\subsubsection{Evaluasi Keperawatan}

Perawat kesehatan jiwa mengevaluasi perkembangan pasien dalam mencapai hasil yang diharapkan. Asuhan keperawatan adalah proses dinamik yang melibatkan perusahaan dalam status kesehatan pasien sepanjang waktu, pemicu kebutuhan terhadap data baru, berbagai diagnosis, dan modifikisi rencana asuhan. Oleh karena itu, evaluasi merupakan suatu proses penilaian berkesinambungan tentang pengaruh intervensi keperawatan dan regimen pengobatan terhadap status kesehatan pasien dan hasil kesehatan yang diharapkan (Yusuf, 2015). 


\section{BAB 3}

TINJAUAN KASUS

\begin{tabular}{|l|l|}
\hline Nama : Ny.R & Kondisi saat MRS: \\
Usia : 57 tahun & Nyeri kepala atau pusing, mual, \\
Tahun no reg : - & tidak nafsu makan, badan terasa \\
Ruangan : - & lemas, sering kesemutan, gatal \\
Tgl masuk rs: - & pada tubuh dan luka yang tidak \\
Tgl pengkajian :20 & sembuh-sembuh. \\
oktober 2021 & Kondisi saat ini : \\
Alamat : Jalan Anggrek & Ny. R mengeluh nyeri kepala atau \\
Raya Kecamatan Medan & pusing, mual, tidak nafsu makan, \\
Helvetia & badan terasa lemas, sering \\
& kesemutan, gatal pada tubuh, luka \\
& yang tidak sembuh-sembuh, \\
& cemas dengan keadaannya \\
&
\end{tabular}

\subsection{Pengkajian Keperawatan}

\subsubsection{Faktor Predisposisi Dan Faktor Presipitasi}

\begin{tabular}{|c|c|c|c|c|}
\hline \multirow[b]{2}{*}{ Faktor predisposisi } & \multicolumn{3}{|c|}{ Faktor presipitasi } & \multirow[b]{2}{*}{$\begin{array}{l}\text { STRES } \\
\text { SOR }\end{array}$} \\
\hline & Nature & Origin & $\begin{array}{l}\text { Number } \\
\text { \& Timing }\end{array}$ & \\
\hline $\begin{aligned} & \text { Biologis: } \\
& \text { 1. } \\
& \text { 2. } \text { Ny. R } \\
& \text { 3. } \text { menderita penyakit DM } \\
& \text { sejak 1 tahun yang lalu } \\
& \text { 4. } \text { Ny.R kurang mengontrol } \\
& \text { pola makan }\end{aligned}$ & $\begin{array}{l}\text { Nyeri kepala } \\
\text { atau pusing, } \\
\text { mual, tidak } \\
\text { nafsu makan, } \\
\text { badan terasa } \\
\text { lemas, sering } \\
\text { kesemutan, } \\
\text { gatal pada } \\
\text { tubuh dan luka }\end{array}$ & Internal & $\begin{array}{l}\text { Sejak } \\
\text { dilakukan } \\
\text { pengkajian }\end{array}$ & - $\mathrm{DM}$ \\
\hline
\end{tabular}




\begin{tabular}{|c|c|c|c|c|}
\hline & $\begin{array}{l}\text { yang tidak } \\
\text { sembuh- } \\
\text { sembuh }\end{array}$ & & & \\
\hline $\begin{aligned} & \text { Psikologis : } \\
& \text { 1. } \text { Ny.R memiliki kepribadian } \\
& \text { yang terbuka setiap ada } \\
& \text { masalah akan } \\
& \text { 2. } \text { membicarakan kepada } \\
& \text { suami dan anaknya } \\
& \text { 3. } \text { Ny. R merasa gemetaran } \\
& \text {,luka lama sembuh dan } \\
& \text { juntung berdebar kencang }\end{aligned}$ & 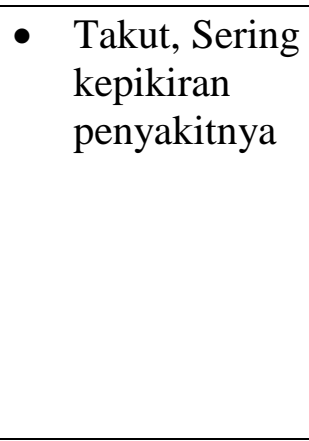 & Internal & $\begin{array}{l}\text { Sejak 1 } \\
\text { bulan } \\
\text { yang lalu }\end{array}$ & $\begin{array}{l}\text { - Cema } \\
\text { s, } \\
\text { takut } \\
\text { panik } \\
\text { an, } \\
\text { khaw } \\
\text { atir }\end{array}$ \\
\hline $\begin{array}{l}\text { Sosiocultural : } \\
\text { 1. Ny. R seorang perempuan } \\
\text { berumur } 57 \text { tahun } \\
\text { 2. Ny. R menikah dan } \\
\text { memiliki } 3 \text { orang anak } \\
\text { 3. Ny.R merupakan ibu } \\
\text { rumah tangga } \\
\text { 4. Ny.R beragama Kristen } \\
\text { dan taat menjalankan } \\
\text { ibadah } \\
\text { 5. Sebelumnya aktif dalam } \\
\text { kegiatan lingkungannya }\end{array}$ & & & & \\
\hline GENOGRAM & & & \multicolumn{2}{|c|}{$\begin{array}{l}\text { Ny.R setelah menikah } \\
\text { dan memilki } 3 \text { orang } \\
\text { anak, Ny.W tinggal } \\
\text { bersama suami dan } \\
\text { ke-3 orang anaknya }\end{array}$} \\
\hline
\end{tabular}




\subsubsection{Penilaian (Respon)Terhadap Stressor}

\begin{tabular}{|c|c|c|c|c|c|c|}
\hline STRESSOR & KOGNITIF & AFEKTIF & FISIOLOGIS & PERILAKU & SOSIAL & \begin{tabular}{|c|} 
DIAGNOSA \\
KEPERAWA \\
TAN \\
\end{tabular} \\
\hline $\begin{array}{l}\text { BIOLOGIS } \\
\text { - DM }\end{array}$ & $\begin{array}{l}\text { - Penyakit } \\
\text { DM yang } \\
\text { dideritanya } \\
\text { dikarenaka } \\
\text { n Ny.R } \\
\text { tidak } \\
\text { mengkontr } \\
\text { ol pola } \\
\text { makannya. } \\
\text { - Ny.R } \\
\text { merasa } \\
\text { penyakitn } \\
\text { ya ini } \\
\text { cukup } \\
\text { berat }\end{array}$ & $\begin{array}{ll}\text { Ny.R } \\
\text { merasa } \\
\text { sedih } \\
\text { dan } \\
\text { merasa } \\
\text { takut } \\
\text { karena } \\
\text { kondisi } \\
\text { penyakit } \\
\text { nya }\end{array}$ & $\begin{array}{ll}\text { - } & \text { Pusing } \\
\text { - } & \text { Tidak } \\
\text { nafsu } \\
\text { makan } \\
\text { - } \text { Ny.R } \\
\text { tampak } \\
\text { lemas } \\
\text { - Sulit tidur } \\
\text { - } \text { Badan } \\
\text { terasa gatal } \\
\text { - Pemeriksaa } \\
\text { n TTV } \\
\text { TD: } 140 / 100 \\
\text { mmhg } \\
\mathrm{N}: 88 \quad \text { x / } \\
\text { menit } \\
\mathrm{P}: 22 \quad \mathrm{x} / \\
\text { menit } \\
\mathrm{S}: 37{ }^{0} \mathrm{C}\end{array}$ & $\begin{array}{ll}\text { - } & \text { Ny.R } \\
\text { tampak } \\
\text { gelisah } \\
\text { dan } \\
\text { khawati } \\
\text { r } \\
\text { - } \text { Wajah } \\
\text { Ny.R } \\
\text { tampa } \\
\text { k lesu }\end{array}$ & $\begin{array}{l}\text { - Ny.R } \\
\text { mengujung } \\
\text { i fasilitas } \\
\text { kesehatan } \\
\text { untuk } \\
\text { mendapatk } \\
\text { an } \\
\text { perawatan } \\
\text { ataupun } \\
\text { pengobata } \\
\text { n terhadap } \\
\text { penyakit } \\
\text { yang } \\
\text { dialaminya }\end{array}$ & - Ansietas \\
\hline $\begin{array}{l}\text { PSIKOLOGI } \\
\text { S } \\
\text { Sedih, cemas } \\
\text { karena tidak } \\
\text { dapat } \\
\text { melakukan } \\
\text { pekerjaan } \\
\text { seperti } \\
\text { biasanya dan } \\
\text { juga bingung } \\
\text { dengan } \\
\text { kondisi } \\
\text { penyakitnya }\end{array}$ & $\begin{array}{l}\text { - Ny.R } \\
\text { merasa } \\
\text { tidak } \\
\text { berdaya } \\
\text { karena } \\
\text { tidak bisa } \\
\text { bekerja } \\
\text { seperti } \\
\text { biasanya } \\
\text { karena } \\
\text { kondisiny } \\
\text { a yang } \\
\text { lemah dan } \\
\text { luka yang } \\
\text { tidak } \\
\text { kunjung } \\
\text { sembuh } \\
\text { Ny.R juga } \\
\text { merasa } \\
\text { bosan di } \\
\text { rumah dan } \\
\text { tidak tau }\end{array}$ & $\begin{array}{l}\text { Merasa } \\
\text { cemas } \\
\text { karena } \\
\text { penyakitn } \\
\text { ya yang } \\
\text { tidak } \\
\text { kunjung } \\
\text { sembuh }\end{array}$ & $\begin{array}{l}\text { - Pusing } \\
\text { - Mual } \\
\text { - Sulit tidur } \\
\text { - Tidak } \\
\text { nafsu } \\
\text { makan } \\
\text { - Ny.R } \\
\text { tampak } \\
\text { lemas } \\
\text { - Tampak } \\
\text { Lemah } \\
\text { - Wajah } \\
\text { pucat } \\
\text { - Pemeriksaa } \\
\text { n TTV } \\
\text { TD: } 140 / 100 \\
\text { mmhg } \\
\text { N : } 88 \text { x / } \\
\text { menit } \\
\text { P : } 20 \text { x / } \\
\text { menit }\end{array}$ & 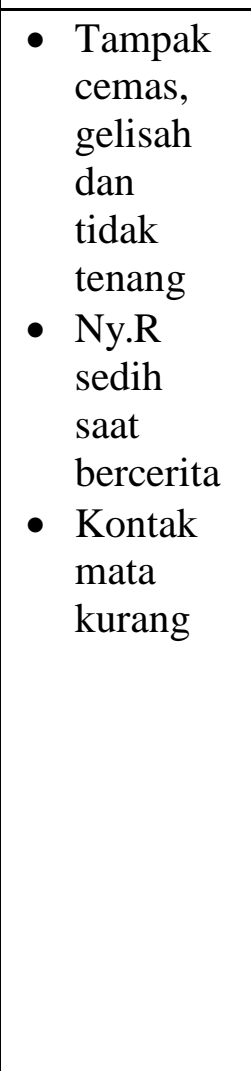 & $\begin{array}{l}\text { - Hubungan } \\
\text { Ny.R } \\
\text { dengan } \\
\text { suami dan } \\
\text { anaknya } \\
\text { baik } \\
\text { - Ny.R } \\
\text { berhubung } \\
\text { an baik } \\
\text { dengan } \\
\text { keluargany } \\
\text { a } \\
\text { Mengikuti } \\
\text { program } \\
\text { pengobata } \\
\text { n yang } \\
\text { diberikan } \\
\text { kepadanya } \\
\text { akan tetapi } \\
\text { sikap Ny.R } \\
\text { pasif saat }\end{array}$ & $\begin{array}{l}\text { Ketidak } \\
\text { berdayaan }\end{array}$ \\
\hline
\end{tabular}




\begin{tabular}{|c|c|c|c|c|c|c|}
\hline & $\begin{array}{l}\text { pengobata } \\
\text { n yang } \\
\text { bagaimana } \\
\text { lagi untuk } \\
\text { menyembu } \\
\text { hkan } \\
\text { penyakitny } \\
\text { a }\end{array}$ & & S: $36^{0} \mathrm{C}$ & & $\begin{array}{l}\text { menerima } \\
\text { perawatan }\end{array}$ & \\
\hline $\begin{array}{l}\text { SOSIAL } \\
\text { BUDAYA } \\
\text { Merasa } \\
\text { kasihan } \\
\text { dengan suami } \\
\text { dan anaknya }\end{array}$ & $\begin{array}{l}\text { - Ny.R } \\
\text { merasa } \\
\text { kasihan } \\
\text { dengan } \\
\text { suami } \\
\text { dan } \\
\text { anaknya } \\
\text { karena } \\
\text { semenjak } \\
\text { dia sakit } \\
\text { suami } \\
\text { dan } \\
\text { anaknya } \\
\text { yang } \\
\text { harus } \\
\text { menggant } \\
\text { ikan } \\
\text { perannya, } \\
\text { sedangka } \\
\text { n } \\
\text { suaminya } \\
\text { harus } \\
\text { bekerja } \\
\text { dan } \\
\text { anaknya } \\
\text { harus } \\
\text { bekerja } \\
\text { dan } \\
\text { bersekola } \\
\text { h }\end{array}$ & $\begin{array}{l}\text { - Merasa } \\
\text { sedih } \\
\text { dan } \\
\text { khawatir } \\
\text { merepot } \\
\text { kan } \\
\text { suami } \\
\text { dan } \\
\text { anaknya }\end{array}$ & $\begin{array}{l}\text { - Pusing } \\
\text { - Mual } \\
\text { - Sulit tidur } \\
\text { - Tampak } \\
\text { lemah } \\
\text { - Tidak } \\
\text { nafsu } \\
\text { makan }\end{array}$ & $\begin{array}{ll}\text { - } & \text { Tampak } \\
& \text { sedih } \\
\text { - } & \text { Volume } \\
\text { suara } \\
\text { mengecil } \\
\text { - } & \text { Eksperesi } \\
\text { wajah } \\
\text { Ny.R } \\
\text { tampak } \\
\text { khawatir }\end{array}$ & $\begin{array}{l}\text { - Hubunga } \\
\text { n Ny. R } \\
\text { dengan } \\
\text { suami } \\
\text { dan anak } \\
\text { baik } \\
\text { - Hubunga } \\
\text { n Ny.R } \\
\text { dengan } \\
\text { petugas } \\
\text { kesehata } \\
\text { n baik } \\
\text { - Ny. R } \\
\text { tetap } \\
\text { mengikut } \\
\text { i } \\
\text { program } \\
\text { pengobat } \\
\text { an }\end{array}$ & \begin{tabular}{|l} 
- Penampila \\
n peran \\
tidak \\
efektif
\end{tabular} \\
\hline
\end{tabular}




\subsubsection{Sumber Koping}

\begin{tabular}{|c|c|c|c|c|c|}
\hline $\begin{array}{c}\text { DIAGNOSA } \\
\text { KEPERAWATAN }\end{array}$ & $\begin{array}{c}\text { PERSONAL } \\
\text { ABILITY }\end{array}$ & $\begin{array}{c}\text { SOSIAL } \\
\text { SUPPORT }\end{array}$ & $\begin{array}{l}\text { MATERIL } \\
\text { ASSETS }\end{array}$ & $\begin{array}{l}\text { POSITIE } \\
\text { BELIEFS }\end{array}$ & TERAPI \\
\hline Ansietas & $\begin{array}{ll}\text { - } & \text { Ny.R mampu } \\
\text { mengungkapkan } \\
\text { perasaancemas }\end{array}$ - $\begin{array}{l}\text { Ny.R mampu } \\
\text { mengenal dan } \\
\text { menilai } \\
\text { penyebab } \\
\text { kecemasannya } \\
\text { - } \\
\text { Ny. R mampu } \\
\text { melakukan } \\
\text { terapi yang } \\
\text { diajarkan }\end{array}$ & $\begin{array}{l}\text { - Ny.R } \\
\text { mendapat } \\
\text { dukungan } \\
\text { dari keluarga } \\
\text { untuk } \\
\text { kesembuhann } \\
\text { ya terutama } \\
\text { dari } \\
\text { Suaminya } \\
\text { dan anaknya }\end{array}$ & $\begin{array}{ll}\text { - } & \text { Ekonomi } \\
\text { Ny.R } \\
\text { menengah } \\
\text { - Pengobatan } \\
\text { ditanggung } \\
\text { BPJS } \\
\text { - Jarak rumah } \\
\text { Ny.R dengan } \\
\text { tempat } \\
\text { pelayanan } \\
\text { kesehatan } \\
\text { lebih kurang } \\
\text { 2KM }\end{array}$ & $\begin{array}{l}\text { - Ny.R percaya } \\
\text { bahwa petugas } \\
\text { kesehatan akan } \\
\text { membantunya } \\
\text { Ny.R berharap } \\
\text { cepat sembuh } \\
\text { agar tidak } \\
\text { merepotkan } \\
\text { Suami dan } \\
\text { anaknya }\end{array}$ & $\begin{array}{|ll|}\text { Terapi generalis: } \\
\text { - } & \text { SP 1-4 kecemasan } \\
& \text { untuk individu } \\
\text { Terapi Spesialis : } \\
\text { - } & \text { Relaksasi } \\
& \text { progresif } \\
\text { - } & \text { Psikoedukasi } \\
& \text { keluarga }\end{array}$ \\
\hline Ketidak Berdayaan & $\begin{array}{l}\text { Ny.R mengakui } \\
\text { bahwa ia } \\
\text { merasa tidak } \\
\text { berdaya untuk } \\
\text { melakukan } \\
\text { aktivitas seperti } \\
\text { biasa karena } \\
\text { penyakitnya }\end{array}$ & $\begin{array}{l}\text { - Ny.R } \\
\text { mendapat } \\
\text { dukungan } \\
\text { dari keluarga } \\
\text { untuk } \\
\text { kesembuhann } \\
\text { ya terutama } \\
\text { dari } \\
\text { Suaminya } \\
\text { dan anaknya }\end{array}$ & 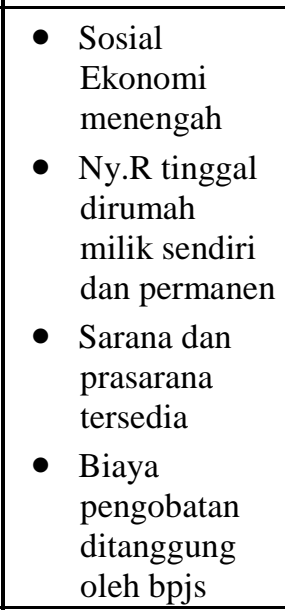 & $\begin{array}{l}\text { - Ny.R percaya } \\
\text { bahwa petugas } \\
\text { kesehatan akan } \\
\text { membantunya } \\
\text { - Ny.R berharap } \\
\text { agar cepat } \\
\text { sembuh dan } \\
\text { tidak } \\
\text { merepotkan } \\
\text { Ny.R selalu } \\
\text { berdoa untuk } \\
\text { kesembuhan } \\
\text { penyakitnya }\end{array}$ & \begin{tabular}{|l|} 
Terapi generalis : \\
SP1-2 \\
Ketidakberdayaan \\
Terapi Spesialis : \\
$\quad$ Terapi assesment \\
$\quad$ ketidakberdyaan \\
$\quad$ Latihan berpikir \\
positif
\end{tabular} \\
\hline $\begin{array}{l}\text { Penampilan peran } \\
\text { tidak efektif }\end{array}$ & $\begin{array}{l}\text { - Ny.R dapat } \\
\text { menyebutk } \\
\text { an } \\
\text { penyebab } \\
\text { penampilan } \\
\text { peran tidak } \\
\text { efektif } \\
\text { - Ny.R } \\
\text { mengang } \\
\text { gap } \\
\text { suami } \\
\text { tidak } \\
\text { mampu } \\
\text { sebagai } \\
\text { penggant } \\
\text { i akibat } \\
\text { kondisi } \\
\text { yang } \\
\text { berubah }\end{array}$ & $\begin{array}{l}\text { - Ny.R } \\
\text { mendapat } \\
\text { dukungan } \\
\text { dari } \\
\text { keluarga } \\
\text { untuk } \\
\text { kesembuha } \\
\text { nnya } \\
\text { terutama } \\
\text { dari } \\
\text { Suaminya } \\
\text { dan } \\
\text { anaknya } \\
\text { Keluarga } \\
\text { Ny.R selalu } \\
\text { menyemang } \\
\text { ati klien }\end{array}$ & $\begin{array}{ll}\text { Ekonomi } \\
\text { Ny.R } \\
\text { menengah } \\
\text { - Pengobatan } \\
\text { ditanggung } \\
\text { BPJS } \\
\text { - Jarak rumah } \\
\text { Ny.R dengan } \\
\text { tempat } \\
\text { pelayanan } \\
\text { kesehatan } \\
\text { lebih kurang } \\
\text { 2KM }\end{array}$ & $\begin{array}{ll}\text { Ny.R selalu } \\
\text { berdoa untuk } \\
\text { kesembuhan } \\
\text { penyakitnya } \\
\text { - } \\
\text { Ny.R yakin, bila } \\
\text { ia mengikuti } \\
\text { petunjuk dan } \\
\text { saran dari } \\
\text { petugas } \\
\text { kesehatan maka } \\
\text { ia akan cepat } \\
\text { sembuh } \\
\text { - Ny.R yakin } \\
\text { suami dan } \\
\text { anaknya } \\
\text { mendukung } \\
\text { supaya lekas } \\
\text { sembuh } \\
\text { Ny.R percaya } \\
\text { bahwa petugas } \\
\text { kesehatan akan }\end{array}$ & \begin{tabular}{|l|} 
Terapi Generalis : \\
- \\
SP 1-2 \\
penampilan \\
peran tidak \\
efektif \\
Terapi Spesialis : \\
- \\
Behavior \\
therapy, terapi \\
suportif
\end{tabular} \\
\hline
\end{tabular}




\begin{tabular}{|l|l|l|l|l|}
\hline & & & & $\begin{array}{l}\text { membantunya } \\
\text { Ny.R berharap } \\
\text { cepat sembuh } \\
\text { agar tidak } \\
\text { merepotkan } \\
\text { suamidan } \\
\text { anaknya } \\
\end{array}$ \\
& & & & \\
& & & & \\
& & & & \\
& & & & \\
\end{tabular}

\subsubsection{Mekanisme Koping}

\section{HAL YANG DILAKUKAN}

\section{ANALISA}

- Ny.R mengatakan bila ada masalah, maka ia akan membicarakan dengan suami, anak serta keluarga untuk mencari jalan keluarnya

- Bila sakit Ny.R berobat ke pelayanan kesehatan

- Ny.R taat menjalankan ibadah sesuai dengan keyakinannya

- Ny.R selalu berdoa kepada Tuhan untuk kesembuhannya
- Konstruktif:

$\checkmark \quad$ Ny.R mengatakan bila ada masalah, maka ia akan membicarakan dengan suami, anak dan keluarga untuk mencari jalan keluarnya

$\checkmark$ Bila sakit Ny.R berobat ke pelayanan kesehatan

$\checkmark \quad$ Ny.R taat menjalankan ibadah sesuai dengan keyakinannya

$\checkmark \quad$ Ny.R selalu berdoa kepada Tuhan untuk kesembuhannya.

- Destruktif : - 


\subsubsection{Status Mental}

\begin{tabular}{|l|l|}
\hline 1. Penampilan & Bersih, rapi, tidak tercium bau \\
\hline 2. Pembicaraan & Berbicara dengan jelas \\
\hline 3. Aktivitas motoric & Saat berbicara pasien tampak gelisah \\
\hline 4. Interaksi selamawawancara & Cukup kooperatif \\
\hline 5. Alam perasaan & $\begin{array}{l}\text { Sedih, merasa cemas ,takut dan bingung mengenai kondisi penyakit, suami dan } \\
\text { anak-anaknya }\end{array}$ \\
\hline 6. Afek & Datar \\
\hline 7. Persepsi & Ny.R tidak mengalami gangguan persepsi dan sensori \\
\hline 8. Isi piker & Sesuai dengan realita \\
\hline 9. Proses piker & Baik \\
\hline 10. Tingkat kesadaran & Ny.R dapat menyebutkan kembali nama suami \\
\hline 11. Daya ingat & Ny.R tidak dapat mengingat beberapa kejadian dalam hidupnya \\
\hline 12. Kemampuan berhitung & Kemampuan berhitung cukup baik \\
\hline 13. Penilaian & Ny.R belum mampu menyebutkan bagaimana caranya agar Ny.R lekas sembuh \\
\hline 14. Daya tilik diri & $\begin{array}{l}\text { Ny.R menyadari bahwa saat ini ia sedang sakit, Ny.R hanya bisa berdoa } \\
\text { supaya lekas sembuh agar tidak terus merepotkan suami dan anaknya. } \\
\text { Ny.R menyadari ia memiliki suami, anak-anak dan keluarga yang } \\
\text { menyayanginya dan mendukung kesembuhannya }\end{array}$ \\
\hline
\end{tabular}

Kesimpulan : Mental Status Examination (MSE) tidak ada masalah gangguan jiwa, gangguan

Ny.R lebih kepada Gangguan Mental Emosional (GME/Psikososial)

\subsection{Diagnosa Dan Terapi}

\section{DIAGNOSA KEPERAWATAN DAN TERAPI KEPERAWATAN}

\section{Ansietas}

- Sp1: Kaji tanda dan gejala ansietas dan kemampuan klien mengurangi kecemasan

- Sp2 : Jelaskan tanda dan gejala, penyebab, dan akibat dari kecemasan

- Sp3 : Latihan cara mengatasi kecemasan :

$\checkmark$ Teknik relaksasi napas dalam

$\checkmark$ Distraksi : bercakap-cakap hal positif

$\checkmark$ Hipnotis 5 jari fokus pada hal yang positif

- Sp4 : Bantu klien melakukan latihan sesuai dengan jadwal kegiatan

- Terapi Spesialis : TS, PMR, Logo ACT

\section{Ketidakberdayaan}

Assesment ketidakberdayaan dan latihan berpikir positif

\section{Penampilan peran tidak efektif}

Terapi Perilaku

\section{DIAGNOSA MEDIS}

Diabetes Melitus

- Istirahat yang cukup

- Atur pola makan 


\subsection{Implementasi Tindakan Kperawatan Dan Evaluasi}

\section{IMPLEMENTASI TINDAKAN KPERAWATAN}

Tanggal : 15 Oktober 2021

Jam : 10.00 wib

1. Melakukan salam teraupetik

2. Kaji tanda dan gejala ansietas dan kemampuan klien mengurangi kecemasan

3. Jelaskan tanda dan gejala, penyebab dan akibat dari kecemasan

4. Latihan cara mengatasi kecemasan :

- Teknik relaksasi napas dalam

- Distraksi : bercakap-cakap hal positif

- Hipnotis 5 jari fokus pada hal-hal yang positif

5. Bantu klien melakukan latihan sesuai dengan jadwal kegiatan.

Tanggal : 16 Oktober 2021

Jam : 10.00 wib

1 Latihan cara mengatasi kecemasan :

$\checkmark$ Teknik relaksasi napas dalam

$\checkmark$ Distraksi : bercakap-cakap hal positif

$\checkmark$ Hipnotis 5 jari fokus pada hal-hal yang positif

2 Bantu klien melakukan latihan sesuai dengan jadwal kegiatan

\section{EVALUASI}

S : Pasien senang

$\mathbf{O}$ : Pasien mampu melakukan nafas dalam dengan motivasi

Pasien mampu latihan distraksi dengan mandiri

Pasien mampu melakukan hipnotis 5 jari dengan bantuan

A: Ansietas (+)

P :

- Latihan cara mengatasi kecemasan:

$\checkmark$ Teknik relaksasi napas dalam 3x sehari

$\checkmark$ Distraksi : bercakap-cakap hal positif 3x sehari

$\checkmark$ Hipnotis 5 jari fokus $3 \mathrm{x}$ sehari

$\mathbf{S}$ : Pasien senang

O: Pasien mampu melakukan nanfas dalam dengan motivasi

Pasien mampu latihan distraksi dengan mandiri

Pasien mampu melakukan hipnotis 5 jari dengan bantuan

A: Ansietas (-)

P :

- Latihan relaksasi nafas dalam 3x sehari

- Distraksi 3x sehari

- Latihan hipnotis 5 jari $3 x$ sehari

Tanggal : 17 Oktober 2021

Jam : $10.00 \mathrm{wib}$

S : Pasien senang

O: Pasien mampu melakukan nanfas

dalam dengan motivasi

Pasien mampu latihan distraksi

dengan mandiri

Pasien mampu melakukan hipnotis 5

jari dengan bantuan

A: Ansietas (-)

P:

- Latihan relaksasi nafas dalam 3x sehari

- Distraksi 3x sehari

- Latihan hipnotis 5 jari 3x sehari

Tanggal 18 Oktober 2021

Jam: $10.00 \mathrm{wib}$

1 Latihan cara mengatasi kecemasan : berkurang, pasien sudah merasa lebih tenang.

O : Pasien mampu melakukan nanfas 


\begin{tabular}{|c|c|}
\hline $\begin{array}{ll}\checkmark & \text { Teknik relaksasi napas dalam } \\
\checkmark & \text { Distraksi : bercakap-cakap hal positif } \\
\checkmark & \text { Hipnotis } 5 \text { jari fokus pada hal-hal yang positif } \\
2 & \text { Bantu klien melakukan latihan sesuai dengan } \\
& \text { jadwal kegiatan }\end{array}$ & $\begin{array}{l}\text { dalam dengan motivasi } \\
\text { Pasien mampu latihan distraksi } \\
\text { dengan mandiri } \\
\text { Pasien mampu melakukan hipnotis } 5 \\
\text { jari dengan bantuan. } \\
\text { A : Ansietas (-) } \\
\text { P: } \\
\text { - Latihan relaksasi nafas dalam } 3 x \\
\text { - } \\
\text { - Distraksi } 3 x \text { sehari } \\
\text { - Latihan hipnotis } 5 \text { jari } 3 x \text { sehari }\end{array}$ \\
\hline 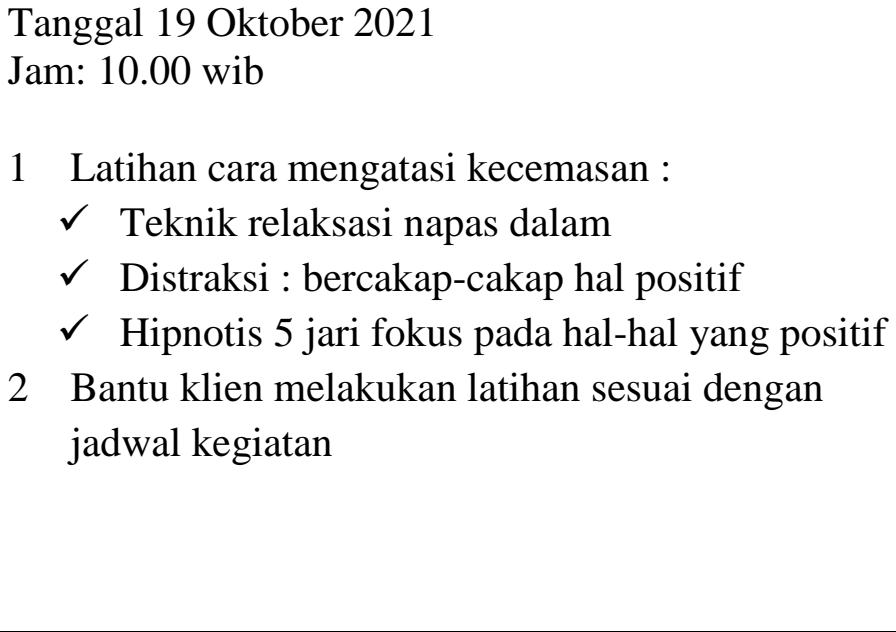 & $\begin{aligned} \mathbf{S}: & \text { senang } \\
\mathbf{O}: & \text { Pasien mampu melakukan nanfas } \\
& \text { dalam dengan motivasi } \\
& \text { Pasien mampu latihan distraksi } \\
& \text { dengan mandiri } \\
& \text { Pasien mampu melakukan hipnotis } 5 \\
& \text { jari dengan bantuan } \\
\text { A : } & \text { Ansietas (-) } \\
\mathbf{P}: & \\
\text { - } & \text { Latihan relaksasi nafas dalam 3x } \\
& \text { sehari } \\
\text { - } & \text { Distraksi } 3 x \text { sehari } \\
\text { - } & \text { Latihan hipnotis } 5 \text { jari } 3 x \text { sehari }\end{aligned}$ \\
\hline 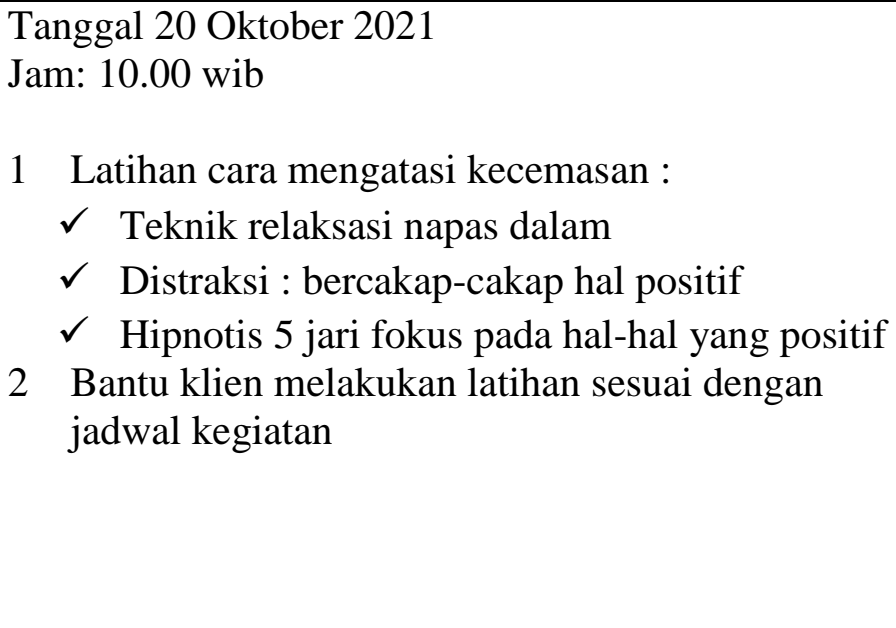 & $\begin{array}{l}\text { S : Pasien senang } \\
\text { O : Pasien mampu melakukan nafas dalam } \\
\text { dengan motivasi } \\
\text { Pasien mampu latihan distraksi } \\
\text { dengan mandiri } \\
\text { Pasien mampu melakukan hipnotis } 5 \\
\quad \text { jari dengan bantuan }\end{array}$ \\
\hline
\end{tabular}




\section{BAB 4}

\section{PEMBAHASAN}

Setelah penulis melaksanakan asuhan keperawatan kepada Ny.R dengan Kecemasan di Jalan Anggrek Raya Kecamatan Medan Helvetia maka penulis pada BAB ini akan membahasan kesenjangan antara teoritis dengan tinjauan kasus. Pembahasan dimulai melalui tahapan proses keperawatan yaitu pengkajian, diagnosa keperawatan, perencanaan, pelaksanaan dan evaluasi.

\subsection{Tahap Pengkajian}

Selama pengkajian dilakukan pengumpulan data dari beberapa sumber, yaitu dari pasien dan tetangga sekitar. Maka penulis melakukan pendekatan kepada pasien melalui komunikasi teraupetik yang lebih terbuka membantu klien untuk memecahkan perasaannya dan juga melakukan observasi kepada pasien. Adapun upaya tersebut yaitu :

a. Melakukan pendekatan dan membina hubungan saling percaya diri pada klien agar klien lebih terbuka dan lebih percaya dengan menggunakan perasaan.

b. Mengadakan pengkajian klien dengan wawancara Dalam pengkajian ini, penulis tidak menemukan kesenjangan karena ditemukan hal sama seperti: diteori: Kecemasan adalah keadaan emosi dan pengalaman subyektif individu, tanpa objek yang spesifik karena ketidaktahuan dan mendahului pengalamanya yang baru seperti penyakitnya saat ini.

\subsection{Tahap perencanaan}

Perencanaan dalam proses keperawatan lebih dikenal dengan rencana asuhan keperawatan yang merupakan tahap selanjutnya setelah pangkajian dan penentuan diagnosa keperawatan. Pada tahap perencanaan penulis hanya menyusun rencana tindakan keperawatan sesuai dengan pohon masalah keperawatan yaitu :Kecemasan. Pada tahap ini antara tinjauan teoritis dan tinjaun kasus tidak ada kesenjangan sehingga penulis dapatmelaksanakan tindakan seoptimal mungkin dan didukung dengan seringnya bimbingan dengan pembimbing.

Secara teoritis digunakan cara strategi pertemuan sesuai dengan diagnosa keperawatan yang muncul saat pengkajian. Adapun upaya yang dilakukan penulis yaitu :

1. Klien mengungkapkan ketidakpastian tentang fluktuasi tingkat energi dan bersikap 
pasif.

2. Klien menunjukan sikap apatis, depresi terhadap perburukan fisik yang terjadi dengan mengabaikan kepatuhan pasien terhadap program pengobatan

3. Klien mengalami ketergantungan pada orang lain yang dapat mengakibatkan ititabilitas, ketidaksukaan, marah dan rasa bersalah. Klien tidak melakukan praktik perawatan diri ketika ditantang. Klien tidak ikut memantau kemajuan pengobatan. Klien menunjukan ekspresi ketidakpuasan terhadap ketidakmampuan melakukanaktivitas atau tugas sebelumnya. Klien menunjukan ekspresi keraguan tantang performa peran.

\subsection{Tahap Implementasi}

Pada tahap implementasi, penulis hanya mengatasi 1 masalah keperawatan yakni: diagnosa keperawatan Kecemasan merupakan keadaan emosi dan pengalaman subyektif individu,tanpa objek spesifik karena ketidaktahuan dan mendahului semua pengalaman yang di alami penyakit Diabetes Melitus.

\subsection{Tahap Evaluasi}

Pada tinjauan teoritis evaluasi yang diharapkan adalah :

a. Membina hubungan saling percaya

b. Mengenali dan mengekspresikan emosinya

c. Mampu mengenal ansietas

d. Mampu mengatasi ansietas melalui teknik releksasi

e. Mampu mengatasi ansietas dengan distraksi

f. Mampu mengatasi ansietas melalui hipnotis lima jari

g. Mampu mengatasi ansietas melalui kegiatan spiritual

Teori menurut Tim Pokja SDKI DPP PPNI (2017), Monitor perubahan sirkulasi (dengan mengukur tanda-tanda vital), Monitor perubahan status nutrisi, Monitor penurunan kelembapan, Gunakan produk berbahan petrolium atau minyak pada kulit kering, Anjurkan mengguanakan pelembab (mis. Lotion,serum), Rawat luka : Monitor karakteristik luka (mis. Drainase warna, ukuran, bau), Monitor tanda-tanda infeksi, Lepaskan balutan dan plester secara berlahan, Bersihkan dengan cairan $\mathrm{NaCl}$ atau pembersih non toksik, Bersihkan jaringan nekrotik, Berikan salep yang sesuai 
kekulit/lesi,jika perlu, Pasang balutan sesuai dengan jenis luka, Pertahankan tehnik steril pada saat perawatan luka, Ganti balutan sesuai jumlah exsudat dan drainase, Edukasi perawatan kulit, Edukasi pola perilaku kebersihan, Edukasi 5 pilar DM , Kolaborasi dengan dokter dan ahli gizi dalam pemberian terapi dan diit, Pemeriksaan gula darah. 


\section{BAB 5}

\section{PENUTUP}

\subsection{Kesimpulan}

Berdasarkan uraian pada pembahasan diatas, maka penulis dapat disimpulkan bahwa:

1. Pengkajian dilakukan secara langsung pada klien dan juga dengan menjadikan status klien sebagai sumber informasi yang dapat mendukung data-data pengkajian. Selama proses pengkajian, perawat mengunakan komunikasi teraupetik serta membina hubungan saling percaya antara perawat-klien. Pada kasus Kecemasan : Diabetes Melitus

2. Diagnosa keperawatan yang utama pada klien dengan Kecemasan: Diabetes Melitus

3. Perencanaan intervensi dan implementasi keperawatan disesuaikan dengan strategi pertemuan pada pasien.

4. Evaluasi keperawatan yang dilakukan menggunakan metode subyektif, obyektif ,assessment dan planing.

\subsection{Saran}

1. Untuk Keluarga

Diharapkan agar individu dan keluarga bisa mengerti tentang penyakit diabetes melitus, dan meningkatkan perilaku hidup sehat dengan tujuan meningkatkan kualitas hidup.

2. Untuk Masyarakat/Pembaca

Diharapkan kasus dan materi ini dapat dijadikan sebagai bahan ajar dan data untuk menangani dan menghadapi kasus kecemasan pada masalah psikososial. 


\section{DAFTAR PUSTAKA}

American Diabetes Association (ADA). (2018). "Foot Care Standards of Medical Care in Diabetes-2018".

http://care.diabetesjournals.org/content/36/Supplement_1/S11.full.pdf+html

Donsu, J.D.T. (2017). Psikologi keperawatan : aspek-aspek Psikologi. Yogyakarta : Pustaka Baru Press

Federation, I. D. (2019). IDF Diabetes Atlas - 2019. In International Diabetes Federation. https://doi.org/10.1289/image.ehp.v119.i03

Hawari, Dadang (2013). Stress, Cemas, dan Depresi. Jakarta : FK UI

Hulu, E. K., \& Pardede, J. A. (2016). Dukungan Keluarga Dengan Tingkat Kecemasan Pasien Pre Operatif Di Rumah Sakit Sari Mutiara Medan. Jurnal Keperawatan, 2(1).

Irawan, E. (2018). Faktor-Faktor Yang Berhubungan Dengan Pengetahuan Masyarakat Tentang Diabetes Mellitus Tipe II. https://doi.org/10.31311/jk.v6i2.4316

Mahmuda, N. L., Thohirun, \& Prasetyowati, I. (2016). Faktor yang Berhubungan dengan Tingkat Kecemasan Penderita Diabetes Mellitus Tipe 2 di Rumah Sakit Nusantara Medika Utama. Artikel Ilmiah Hasil Penelitian Mahasiswa. https://doi.org/10.32583/keperawatan.v13i3.1354

Marbun, A., Pardede, J. A., \& Perkasa, S. I. (2019). Efektivitas Terapi Hipnotis Lima Jari terhadap Kecemasan Ibu Pre Partum di Klinik Chelsea Husada Tanjung Beringin Kabupaten Serdang Bedagai. Jurnal Keperawatan Priority,2(2), 92-99. https://doi.org/10.34012/jukep.v2i2.568

NANDA, (2015). Diagnosis Keperawatan Definisi dan Klasifikasi. Jakarta : ECG.

Owen, H. K. (2016). Hubungan Usia dan Jenis Kelamin Pasien Diabetes Mellitus Tipe 2 terhadap Tingkat Kecemasan Pasien di RSD $d r \quad$ Soebandi Jember.UniversitasJember:FakultasKedokteran. http://repository.unej.ac.id/handle/123456789/78781

Pardede, J. A., Simanjuntak, G. V., \& Waruwu, J. F. A. P. (2020). Penurunan Tingkat Kecemasan Pasien HIV/AIDS melalui Terapi Hipnotis Lima Jari. Coping: Community of Publishing in Nursing, 8, 85-90.

Pardede, J. A., Keliat, B. A., Damanik, R. K., \& Gulo, A. R. B. (2020). Optimalization of Coping Nurses to Overcoming Anxiety in the Pandemic of Covid-19 in Era New Normal. Jurnal Peduli Masyarakat, 2(3), 105-112.

Pardede, J. A. (2020). Standar Asuhan Keperawatan Jiwa Dengan Masalah Kecemasan. 
Pardede, J. A., Safitra, N., \& Simanjuntak, E. Y. (2021). Konsep Diri Berhubungan Dengan Kejadian Depresi Pada Pasien Yang Menjalani Hemodialisa. Jurnal Persatuan Perawat Nasional Indonesia (JPPNI), 5(3), 92-99.

Pardede, J. A., \& Simangunsong, M. M. (2020). Family Support With The Level of Preschool Children Anxiety in the Intravenous Installation. Jurnal KeperawatanJiwa,8(3),223234.doi:https://doi.org/10.26714/jkj.8.3.2020.223-234

Pardede, J. A., \& Tarigan, I. (2020). The Anxiety Level of Mother Presectio Caesar with Benson's Relaxation Therapy. JENDELA NURSING JOURNAL (JNJ), 4(1), 20-28.

PPNI, T. P. S. D. (2018). Definisi dan Tindakan Keperawatan. In Standar Intervensi Keperawatan Indonesia (1st ed., p. 364 365). DPP PPNI.

Report, N. D. S. (2020). National Diabetes Statistics Report, 2020. National Diabetes Statistics Report, 2.

Stuart, G.W. (2013). Buku Saku Keperawatan Jiwa, ed 5. ECG, Jakarta

World Health Organization (2017). Mental disorders fact sheet. World Health Organization . http://www.who.int/mediacentre/factsheets/fs396/en/-

Yusuf, AH., Fitriyasari, R., \& Nihayati, H.E. (2015). Buku Ajar Keperawatan Kesehatan Jiwa. Jakarta: Salemba Medika 